\title{
ANALISA PEMANFAATAN SERABUT SAWIT SEBAGAI BAHAN BAKAR ALTERNATIF PADA BOILER
}

\author{
Untung Surya Dharma \\ Program Studi Teknik Mesin Universitas Muhammadiyah Metro \\ Jl. Ki Hajar Dewantara No. 116 Kota Metro (0725) 42445-42454 \\ Email :untungsdh@yahoo.com
}

\begin{abstract}
ABSTRAK
Dengan semakin berkurangnya persediaan minyak dan energi dunia mengakibatkan terjadinya gejolak harga yang kurang stabil, kemudian fenomena tersebut turut berpengaruh di dalam Negeri hingga menimbulkan keresahan konsumen bahkan situasinya menjadi dilematis bagi kalangan industri. Menghadapi situasi dan kondisi ini akhirnya Pemerintah mengeluarkan himbauan untuk penghematan Energi dan Bahan Bakar Minyak (BBM). Selain itu kalangan industri pengolahan minyak sawit (CPO) juga menghadapi permasalahan yang baru lagi, baik bersifat Teknis dan Non Teknis. Permasalahannya yang terjadi adalah bagaimana penghematan biaya produksi industry, seperti industri pengolahan minyak sawit. Penelitian ini dilaksanakan di PT. Kalirejo Lestari yang beralamat di Kalirejo kabupaten Lampung Tengah Propinsi Lampung. Dari hasil yang telah dianalisa diketahui bahwa perbandingan udara dan bahan bakar adalah sebesar $8,58 \mathrm{~kg}$ udara/kg bahan bakar, hal ini menunjukkan bahwa setiap $1 \mathrm{~kg}$ bahan bakar terdapat $8,58 \mathrm{~kg}$ udara pada proses pembakarannya, sehingga dapat dikatakan bahwa campuran udara dan bahan bakarnya memenuhi kriteria efisiensi termalnya. Hal inidigambarkan pada neraca panas total, terdapat $61702890 \mathrm{kj} / \mathrm{jam}^{\circ} \mathrm{g}^{\circ} \mathrm{C}$ energi panas yang tersisa. Dalam hal ini, untuk memperkecil sisa energi panas dengan cara memperkecil pemasokan bahan bakarnya. Karakteristik pada bahan bakar serabut sawit ini cukup untuk menghasilkan energi panas yang besar. Energi panas yang dihasilkan 21177,36 $\mathrm{Mj} / \mathrm{jamkg}^{\circ} \mathrm{C}$.
\end{abstract}

Kata Kunci: pemanfaatan, serabut sawit, bahan bakar alternatif.

\section{PENDAHULUAN}

Dengan semakin berkurangnya persediaan minyak dan energi dunia mengakibatkan terjadinya gejolak harga yang kurang stabil, kemudian fenomena tersebut turut berpengaruh di dalam Negeri hingga menimbulkan keresahan konsumen bahkan situasinya menjadi dilematis bagi kalangan industri. Menghadapi situasi dan kondisi ini akhirnya Pemerintah mengeluarkan himbauan untuk penghematan Energi dan Bahan Bakar Minyak (BBM).

Karena vitalnya energi dengan volume yang besar maka kalangan industri berupaya mengurangi, bahkan sedapat mungkin bisa terbebas dari kendala dan ketergantungan pada bahan bakar konvesional. Terlebih lagi bagi kalangan industri-industri yang memiliki Mesin Ketel Uap, dimana dalam proses produksinya sangat membutuhkan energi panas. Contohnya adalah Pabrik Crude Palm Oil (CPO) Minyak Sawit dan Palm Kernel Oil (PKO) Minyak Inti Sawit. Selain menghasilkan kelapa sawit, industi perkebunan ini juga menghasilkan limbah yang besar yang berupa tandan kosong, cangkang dan serabut, hingga mencapai 10 juta ton dan terus meningkat setiap tahunnya[1].

Saat ini kalangan industri pengolahan minyak sawit (CPO) juga menghadapi permasalahan yang baru lagi, baik bersifat Teknis dan Non Teknis, permasalahan tersebut adalah :

a) Mencari bahan bakar alternatif yang lebih aman dan sesuai dengan kebutuhan.

b) Menemukan atau mendapatkan teknologi untuk modifikasi ketel uap, agar Ketel Uap yang telah ada masih dapat digunakan. 
c) Banyaknya limbah Serabut sisa dari pengolahan Kelapa Sawit sehingga jika tidak dimanfaatkan limbah tersebut akan menimbulkan permasalahan.

Hal inilah yang memicu beberapa industri untuk beralih penggunaan bahan bakarnya, yang semula menggunakan bahan bakar konvensional mengganti dengan Bahan Bakar Alternatif. Pada industry pengolahan sawit limbah padat, seperti cangkang sawit dan serabut bisa digunakan sebagai bahan bakar padat pada boiler. Apalagi nilai kalor dari cangkang dan serabut cukup tinggi yaitu berturut-turut bernilai $15.000 \mathrm{~kJ} / \mathrm{kg}$ dan 11 $\mathrm{kJ} / \mathrm{kg}$ [2].

\section{LANDASAN TEORI}

\section{Boiler}

Boiler atau Ketel Uap adalah tergolong mesin pembakaran luar. Proses pemanasannya adalah terpisah antara ruang pembakaran dengan tempat air yang dipanasi (fluida kerja) yaitu air yang berada didalam Pipa dipanasi dari luar pipa (peristiwa perebusan), dan akibat dari perebusan tersebut air mendidih hingga berubah menjadi uap [3].

Air dan uap yang di panaskan dan di dinginkan secara simultan bersirkulasi di dalam instalasi pipa dan tabung. Siklus kerja Generator Uap ini berlaku pada Ketel Uap jenis Pipa Air dan Ketel Uap Pipa Api serta Ketel Uap Lorong Api. Tetapi pada Ketel Uap Pipa Api atau Lorong Api terdapat perbebedaan pada cara pemanasanya dibanding dengan Ketel Uap Pipa Air, yaitu selain air dan uap yang bersirkulasi, api atau gas pembakarannya juga ikut beredar didalam pipa atau lorong yang terendam air. Pada pabrik sawit PT. Kalirejo Lestari Lampung [4], dimana penelitian ini dilakukan, jenis Ketel Uap yang digunakan adalah ketel uap Pipa Air, model VikersHoskins(M) SDN BHD serial no. 20572 dengan beberapa peralatan penunjang lainnya.
Bejana bertekanan pada boiler umumnya menggunakan bahan baja dengan spesifikasi tertentu yang telah ditentukan dalam standard ASME (The ASME Code Boilers), terutama untuk penggunaan boiler pada industri industry besar. Dalam sejarah tercatat berbagai macam jenis material digunakan sebagai bahan pembuatan boiler seperti tembaga, kuningan, dan besi cor. Namun bahan-bahan tersebut sudah lama ditinggalkan karena alas an ekonomis dan juga ketahanan material yang sudah tidak sesuai dengan kebutuhan industri. Panas yang diberikan kepada fluida di dalam boiler berasal dari proses pembakaran dengan berbagai macam jenis bahan bakar yang dapat digunakan, seperti kayu, batu bara, solar/ minyak bumi, dan gas. Dengan adanya kemajuan teknologi, energy nuklir pun juga digunakan sebagai sumber panas pada boiler $[5,6]$.

\section{Bahan Bakar}

Proses konversi energi sebagai usaha untuk menghasilkan energi berguna yang langsung dapat dipakai manusia dapat melalui cara yang beragam. Syarat terjadi proses konversi energi: pertama, harus ada sumber energi yang harus dikonversi; kedua, ada alat atau mesin sebagai tempat proses konversi [7]. Apabila kedua syarat terpenuhi proses konversi energi akan berlangsung. Dari keterangan di atas, dapat dinyatakan bahwa sumber energi adalah syarat pertama proses konversi. Sebagai contoh, salah satu dari sekian banyak sumber energi adalah bahan bakar. Adapun definisi dari bahan bakar adalah material, zat atau benda yang digunakan dalam proses pembakaran untuk menghasilkan energi panas. Jadi bahan bakar adalah salah satu sumber energi yang penting. Untuk menghasilkan energi yang dapat dimampatkan bahan bakar harus melalui proses pembakaran. Tanpa proses pembakaran energi tidak dapat diambil dari bahan bakar. 
Dalam pemanfaatan sumber energi, khususnya bahan bakar sekarang ini, selalu ada dua hal yang menjadi perhatian utama yaitu ketersediaannya di alam dan efek samping proses konversi ke lingkungan. Adapun alasan dari dua hal tersebut adalah, pertama kebutuhan manusia akan energi semakin meningkat, hal ini dapat dilihat dari volume penggunaan energi per harinya yang cukup besar. Alasan yang kedua adalah kondisi lingkungan yang semakin kritis dengan adanya pemanasan global. Untuk isu pemanasan global, sekarang ini sedang dicari solusinya untuk mencegah dan mengembalikan keseimbangan sistem alam. Adapun proses pembakaran merupakan salah satu yang dianggap sebagai penyumbang pemanasan global, khususnya dari proses pembakaran bahan bakar fosil yang banyak menghasilkan polutan yang merusak lingkungan. Dari faktor ketersediaanya di alam, bahan bakar dibagi menjadi dua kategori yaitu bahan bakar yang dapat diperbaharui (renewable energi) dan bahan bakar yang tidak dapat diperbaharui. Teknologi yang berkembang pesat adalah mesin-mesin yang mengkonversi sumber energi habis pakai. Saat ini sedang banyak dikembangkan teknologi konversi energi yang dapat diperbaharui. Karena ketergantungan masyarakat yang tinggi dengan ditunjang teknologi yang sudah maju, ketersediaan sumber energi habis pakai di alam mulai kritis untuk beberapa tahun kemudian.

\section{Bahan Bakar Padat}

Bahan bakar padat merupakan salah satu jenis sumber energi yang sudah lama dipakai, bahkan sejak pertama kali manusia mengenal api. Manusia purba menggunkan ranting pohon dan batang pohon untuk membuat api. Dengan semakin berkembangya kemajuan teknologi manusia mulai mencari bahan bakar selain kayu dan selanjutnya ditemukan bahan bakar fosil yaitu batu bara. Dewasa ini batu bara merupakan salah satu sumber energi yang sangat penting. Industri-industri khususnya yang menggunakan tenaga uap sangat bergantung pada batu bara. Ketersedian batu bara di alam masih cukup banyak dibandingkan dengan minyak bumi, sehingga batu bara dapat menjadi pilihan utama di samping bahan bakar nuklir sebagai pengganti minyak bumi.

Bahan bakar yang umum digunakan pada boiler atau ketel uap adalah batu bara $[5,6,7]$. Berdasarkan kandungan karbon, zat terbang dan nilai kalornya, Batu bara yang biasa digunakan pada boiler digolongkan menjadi 4 jenis yaitu :

1. Batu-bara antrasit adalah batu bara yang kualitasnya paling tinggi dengan kandungan karbon yang tinggi yaitu sekitar 86 sampai $98 \%$. Antrasit adalah batu bara yang mengkilap, rapat, keras, dan rapuh.

2. Batu bara bitumin. Batu-bara ini mempunyai kandungan karbon sekitar 20 sampai $40 \%$. Batu bara ini banyak terdapat di alam.

3. Batu bara Subbitumin adalah batu bara yang sejenis bitumin dengan nilai kalor yang lebih rendah dengan kandungan zat terbang (volatil meter) yang lebih tinggi.

4. Batu bara lignit adalah batu bara dengan kualitas paling rendah dengan nilai kalor yang rendah juga.

\section{Proses Pembakaran Bahan Bakar Padat}

Pembakaran merupakan reaksi kimia cepat antara oksigen dan bahan bakar pada suhu tertentu, yang disertai pelepasan suatu kalor [8]. Berdasarkan kondisinya, pembakaran dibagi menjadi tiga, yaitu; pembakaran spontan, pembakaran sempurna dan pembakaran parsial. Sebelum proses pembakaran berlangsung, terlebih dahulu bahan bakar dinaikkan suhunya hingga titik bakarnya tercapai (flash point).

Penguraian dan oksidasi dimulai pada suhu yang rendah ke suhu tinggi. Jika bahan bakar mengandung unsur oksigen dan zat penguap (volatile matter) yang tinggi maka 
suhu penguraian dan oksidasi akan semakin rendah. Pada proses pembakaran biomassa, $80 \%$ energi yang dilepaskan dalam bentuk gas yang mudah terbakar dan sisanya dalam bentuk karbon. Oleh karena itu, selama proses pembakaran sangat penting untuk mempertahankan agar oksigen dapat selalu dijaga dalam kontak dengan bahan bakar dan gas-gas yang terbentuk ketika pembakaran berlangsung pada suhu penyalaannya. Kontak yang baik antara bahan bakar dengan oksigen akan menghasilkan proses pembakaran secara cepat dan komplit, sehingga diperoleh efisiensi pembakaran yang relatif tinggi.

Jika bahan bakar dalam bentuk gas, maka pencampuran reaktan (oksigen dan bahan bakar) dapat dicapai secara optimal karena substansi gas-gas tersebut dapat dengan mudah dicampur secara cepat dan tepat sesuai dengan rasio kebutuhan udara yang diperlukan. Proses pembakarannya pun mungkin dapat terjadi secara cepat, dan kemudian pengontrolannya pun juga lebih cepat terutama dalam penambahan atau pengurangan bahan bakar maupun oksigen yang diperlukan. Supaya proses pembakaran bahan bakar padat berada dalam kondisi yang sama dengan proses pembakaran gas alam, maka bahan bakar biomassa yang dioksidasi perlu direduksi ukurannya menjadi partikelpartikel lebih kecil dari kondisi awalnya. Proses pembakaran pada bahan bakar pada pada umumnya dibagai menjadi 3 tahap, antara lain;

1. Proses pengeringan

2. Proses devolatilisasi

3. Proses pembakarankarbon

\section{Bahan Bakar Serabut Sawit}

Serabut atau pada istilah pabriknya fiber, merupakan hasil produksi sampingan. Bahan tersebut dimanfaatkan sebagian besar industri untuk bahan bakar boiler dengan kapasitas besar. Biasanya serabut yang akan dijadikan bahan bakar dicampur dengan cangkang sawit atau batu bara. Beberapa faktor pencampuran dilakukan untuk menjaga kestabilan suhu dapurnya karena pada saat pengeringan tidak merata, serabut mempunyai kadar moisture yang melebihi standar. Hal tersebut dapat mengakibatkan penggumbalan serta sulit untuk dibakar. Tabel berikut menyajikan komposisi serabut kelapa sawit.

Tabel 1.Komposisi serabut kelapa sawit [4]

\begin{tabular}{|c|c|c|c|}
\hline Komposisi & Persentase (\%) & Komposisi & Perseatase $(\%)$ \\
\hline Kartodititrat & 38.80 & P205 & 2.80 \\
\hline Ghanan & 21.90 & $\mathrm{~K} 20$ & 9.80 \\
\hline Xylan & 15,30 & $\mathrm{MgO}$ & 3.80 \\
\hline Arabionan & 1.60 & $\mathrm{C}_{20}$ & 720 \\
\hline Ligin & $23,+0$ & $\mathrm{SiO}^{2}$ & 62.20 \\
\hline Elstrak Benca & 11.20 & .4202 & 4,50 \\
\hline Ekstraksi air panos & 10.90 & $\mathrm{Fe} 203$ & 390 \\
\hline Kalur baliar hebos air (1talkg) & 4.586 & $\mathrm{~N} 2 \mathrm{O}$ & 0.80 \\
\hline$A b u\left(50^{\circ} \mathrm{C}\right)$ & 5.10 & SO3 & 280 \\
\hline Nitrogen & 0.61 & $\mathrm{CO} ?$ & 2.20 \\
\hline
\end{tabular}

\section{Parameter perhitungan pembakaran}

Beberapa parameter - parameter pembakaran merupakan nilai dari suatu pembakaran dalam menghasilkan suatu daya, apabila pada boiler hasil dari pembakaran adalah uap [9]. Beberapa parameter pembakaran ini dijelaskan sebagai berikut:

a. Reaksi pembakaran

Udara adalah zat pembakar atau oksigen yang dibutuhkan dalam proses pembakaran. Tetapi merupakan campuran bahan bakar bahan bakar dan udara.Didalam udara tidak hanya terdiri dari zat pembakar saja, tetapi juga terdapat bermacam - macam gas lain. Berikut ini disajikan susunan dan prosentase gas gas yang terkandung dalam udara. Prosentase volume :

a. Zat lemas (nitrogen) $\pm 79 \%$,

b. Zat pembakar (oksigen) $\pm 21 \%$,

c. Bermacam - macam gas lain $\pm 1 \%$

Namun pada kenyataannya, udara didalam ruang bakar juga terdapat kotoran - kotoran berukuran kecil seperti debu dan 
lain - lain. Untuk rumus molekulnya dapat dituliskan secara umum sebagai berikut :

$$
\begin{aligned}
\mathrm{C}_{n} \mathrm{H}_{m}+m_{\mathrm{O}_{2}}\left(\mathrm{O}_{2}\right. & \left.+3,76 \mathrm{~N}_{2}\right) \\
& \rightarrow x \mathrm{CO}_{2}+y \mathrm{H}_{2} \mathrm{O}+z \mathrm{O}_{2}+w \mathrm{~N}_{2}
\end{aligned}
$$

Dimana $m_{\mathrm{O}_{2}}$ merupakan massa mol $\mathrm{O}_{2}$ pada pembakaran, sedangkan $\mathrm{x}, \mathrm{y}, \mathrm{z}$ dan $\mathrm{w}$ adalah banyaknya unsur kimia pada produk setelah pembakaran.

b. Perbandingan udara dan bahan bakar

Parameter yang menghubungkan jumlah udara yang digunakan pada proses pembakaran adalah rasio udara - bahan bakar (air-fuel, AF).

$$
A F=\frac{m_{\text {udara }}}{m_{\text {bahan bakar }}}
$$

Dijelaskan bahwa pembakaran hidrokarbon melibatkan $\mathrm{H}_{2} \mathrm{O}$ dalam produk produk hasil pembakarannya. Kita ketahui bahwa berat molekul udara adalah sebesar 29 $\mathrm{kg} / \mathrm{kmol}$.

\section{ANALISA DAN PEMBAHASAN}

\section{Analisa bahan bakar serabut sawit}

\section{a. Reaksi pembakaran}

Diketahui bahwa komposisi serabut sawit $\mathrm{C}: 42,6 \%, \mathrm{H}_{2}: 5,2 \%$, dan $\mathrm{O}_{2}: 32,1$ $\%$, dengan mengabaikan $\mathrm{H}_{2} \mathrm{O}$ dan $\mathrm{S}$ karena pada pengamsumsian dikatakan bahwa unsur $\mathrm{S}$ dan $\mathrm{H}_{2} \mathrm{O}$ merupakan unsur yang tidak terbakar. Dalam hal ini $\mathrm{S}$ (sulfur) adalah unsur menyerupai tanah, dan $\mathrm{H}_{2} \mathrm{O}$ merupakan air, apabila $\mathrm{H}_{2} \mathrm{O}$ mencapai titik panas tertentu (diatas $100^{\circ} \mathrm{C}$ ) $\mathrm{H}_{2} \mathrm{O}$ akan menguap, $\mathrm{H}_{2} \mathrm{O}$ ini tercipta karena adanya pengepresan sawit. Sehingga reaksi pembakarannya menjadi:

$$
\begin{aligned}
& \mathrm{C}_{42,6} \mathrm{H}_{5,2}+32,1\left(\mathrm{O}_{2}+3,76 \mathrm{~N}_{2}\right) \\
& \rightarrow \mathrm{aCO}_{2}+b \mathrm{H}_{2} \mathrm{O}+\mathrm{cO}_{2}+d N_{2}
\end{aligned}
$$

Diketahui pula, bahwapada udara terdapat $21 \% \mathrm{O}_{2}$ dan $79 \% \mathrm{~N}_{2}$, maka pada massa mol $\mathrm{O}_{2}=0,79 / 0,21=3,76 \mathrm{~mol}$ nitrogen dan $1 \mathrm{~mol} \mathrm{O}_{2}+3,76 \mathrm{~mol} \mathrm{~N} \mathrm{~N}_{2}=4,76$ mol udara, jadi :

$$
\begin{array}{llc}
\mathrm{C}: & 42,6=a \rightarrow & a=42,6 \\
\mathrm{H}: & 5,2=2 b \rightarrow & b=2,6 \\
\mathrm{O}: & 32,1 \times 2=2 a+b+2 c & \\
& 64=2.42,6+2,6+2 c & \\
& 64=85,2+2,6+2 c & \\
& 64=87,8+2 c & \\
& 2 c=87,8-64 & \\
& 2 c=23,8 & \\
\mathrm{~N}_{2}: & c=23,8 / 2 \rightarrow & c=11,9 \\
& (32,1)(3,76)=d & \\
& 120,67=d \rightarrow & d=120,67
\end{array}
$$

Sehingga apabila sisa pembakaran ditulis $\mathrm{CO}_{2}, \mathrm{H}_{2} \mathrm{O}, \mathrm{O}_{2}$ dan $\mathrm{N}_{2}$. Maka :

$$
\begin{aligned}
\mathrm{C}_{42,6} \mathrm{H}_{5,2}+32,1\left(\mathrm{O}_{2}+3,76 \mathrm{~N}_{2}\right) & \\
\rightarrow & 42,6 \mathrm{CO}_{2}+2,6 \mathrm{H}_{2} \mathrm{O}+11,9 \mathrm{O}_{2}+120,67 \mathrm{~N}_{2}
\end{aligned}
$$

Sehingga perbandingan udara dan bahan bakar menjadi sebesar:

$$
\begin{aligned}
A F & =\frac{m_{\text {udara }}}{m_{\text {bahan bakar }}} \\
A F & =\frac{4431,1 \mathrm{~kg} \text { udara }}{516,4 \mathrm{~kg} \mathrm{bahan} \mathrm{bakar}} \\
A F & =8,58 \mathrm{~kg} \mathrm{udara} / \mathrm{kg} \text { bahan bakar }
\end{aligned}
$$

\section{b. Kebutuhan panas}

1. Entalpi uap panas lanjut

Diketahui bahwa temperatur air mendidih adalah $100^{\circ} \mathrm{C}$ dalam tekanan 1 atm, maka dari tabel didapat bahwa nilai $\mathrm{r}=1,318 \mathrm{kj} / \mathrm{kg}$, dengan entalpi uap dengan temperatur $300^{\circ} \mathrm{C}$ tekanan $20 \mathrm{~kg} / \mathrm{cm}^{2}$ adalah $3024 \mathrm{kj} / \mathrm{kg}$.

2. Entalpi air

$W_{1}=T_{1} \times$ panas jenis air

Diketahui bahwa panas jenis air adalah $4,187 \mathrm{kj} / \mathrm{kg}$, maka :

$$
\begin{aligned}
& W_{1}=90^{\circ} \mathrm{C} \times 4,187 \mathrm{kj} / \mathrm{kg} \\
& W_{1}=376,83 \mathrm{kj} / \mathrm{kg}{ }^{\circ} \mathrm{C}
\end{aligned}
$$

3. Jumlah panas

Diketahui bahwa kapasitas boiler $(\mathrm{G})$ 80 ton uap/jam atau $80000 \mathrm{~kg}$ uap/jam, maka : 
$Q=G \times \Delta$ entalpi

$Q=G \times($ entalpi uap panas lanjut - entalpi air $)$

$Q=80000 \mathrm{~kg} \mathrm{uap} / \mathrm{jam} \times(3024-376,83) \mathrm{kj} / \mathrm{kg} 12^{\circ} \mathrm{C}$

$Q=211773600 \mathrm{kj} / \mathrm{jam}{ }^{\circ} \mathrm{C}$

$Q=21177,36 \mathrm{Mj} / \mathrm{jam} \quad{ }^{\circ} \mathrm{C}$

\section{c. Perhitungan serabut}

1. Ketersediaan bahan bakar

Diketahui bahwa kapasitas giling pabrik adalah 720 ton/day atau 30 ton/jam atau $30000 \mathrm{~kg} / \mathrm{jam}$.

Quantity $=17,5 \% \times T B S$

Quantity $=0,175 \times 30000 \mathrm{~kg} / \mathrm{jam}$

Quantity $=5250 \mathrm{~kg} / \mathrm{jam}$

2. Produksi panas

$$
\begin{aligned}
Q \text { Production }= & \text { Quantity } \times \text { LHV } \\
Q \text { Production }= & 5250 \mathrm{~kg} \frac{\mathrm{uap}}{\mathrm{jam}} \\
& \times 15534,56 \mathrm{kj} / \mathrm{kg} \\
Q \text { Production }= & 81556440 \mathrm{kj} / \mathrm{jam}
\end{aligned}
$$

3. Kebutuhan panas boiler

$$
\begin{aligned}
& Q \text { Consumption }=\frac{\text { Quantity }(i-w)}{\eta \text { boiler }} \\
& Q \text { Consumption } \\
& =\frac{5250 \mathrm{~kg} \mathrm{uap} / \mathrm{jam}(3024-376,83) \mathrm{kj} / \mathrm{kg}{ }^{\circ} \mathrm{C}}{0,70} \\
& Q \text { Consumption }=19853550 \mathrm{kj} / \mathrm{jam}{ }^{\circ} \mathrm{C}
\end{aligned}
$$

4. Neraca panas total (NPT)

$$
\begin{aligned}
& N P T=Q \text { Production }-Q \text { Consumption } \\
& N P T=81556440 \mathrm{kj} / \mathrm{jam}-19853550 \mathrm{kj} / \mathrm{jam}{ }^{\circ} \mathrm{C} \\
& \quad N P T=61702890 \mathrm{kj} / \mathrm{jam}{ }^{\circ} \mathrm{C}
\end{aligned}
$$

\section{Pembahasan}

Dari hasil yang telah dianalisa diketahui bahwa perbandingan udara dan bahan bakar adalah sebesar $8,58 \mathrm{~kg}$ udara/kg bahan bakar, hal ini menunjukkan bahwa setiap $1 \mathrm{~kg}$ bahan bakar terdapat $8,58 \mathrm{~kg}$ udara pada proses pembakarannya, sehingga dapat dikatakan bahwa campuran udara dan bahan bakarnya memenuhi kriteria efisiensi termalnya. Hal ini digambarkan pada neraca panas total, terdapat $61702890 \mathrm{kj} / \mathrm{jam}{ }^{\circ} \mathrm{C}$ energi panas yang tersisa. Dalam hal ini, untuk memperkecil sisa energi panas dengan cara memperkecil pemasokan bahan bakarnya. Karakteristik pada bahan bakar serabut sawit ini cukup untuk menghasilkan energi panas yang besar. Energi panas yang dihasilkan yaitu sebesar $21177,36 \mathrm{Mj} / \mathrm{jam}{ }^{\circ} \mathrm{C}$.

\section{KESIMPULAN}

Dari hasil analisa, dapat disimpulkan bahwa :

1. Besarnya kebutuhan panas boiler mencapai $19853550 \mathrm{kj} / \mathrm{jam}{ }^{\circ} \mathrm{C}$.

2. Neraca Panas Total (NPT) $61702890 \mathrm{kj} / \mathrm{jam}{ }^{\circ} \mathrm{C}$.

\section{DAFTAR PUSTAKA}

[1] Sudrajat. R., 2004, The Potential of Biomass Energy Resources in Indonesia for The Possible Development of Clean Technology Process, The International Workshop on Biomass \& Clean Fossil Fuel Power Plant Technology, Jakarta, Indonesia.

[2] Irhan Febijanto, 2007, Potensi Biomassa Indonesia Sebagai bahan Bakar Pengganti Energi Fossil, Jurnal Sains dan Teknologi Indonesia, Vol. 9 hal. 6575.

[3] E.S.M. Tambunan, Ir. 1984. Ketel Uap. PT. Suryandaru Utama. Semarang.

[4] PT. Kalirejo Lestari Pabrik Sawit Kalirejo. Boiler Manual Book. 2013

[5] LA. De Bruijn., 1982, Ketel Uap. Bhratara Karya Aksara. Jakarta.

[6] M.J. Djokosetyardjo, Ir. 2003. Ketel Uap. PT. Pradnya Paramita. Jakarta.

[7] Misnah Pantono, BE. 1979. Pesawat Tenaga Kalor. Dikmenjur, Jakarta.

[8] Cengel. Yunus. A., Boles. Michael. A., 2005, Thermodynamics. An Engineering Approach, Fith Edition, E-Book.

[9] Mevin Emil Simanjuntak, 2010, Perancangan Geometri Boiler dan Konfigurasi PLTU dengan Daya 7,3 MW Berbahan Bakar Cangkang Sawit, Jurnal Dinamis, Vol. 1, No. 7. ISSN 0216-7492. 